\title{
Amyloid in intervertebral discs: a histopathological investigation of surgical material from 100 consecutive operations on herniated discs
}

\author{
CHR LADEFOGED, ${ }^{1}$ OLE FEDDERS, ${ }^{2}$ AND OLE FRITZ PETERSEN ${ }^{3}$ \\ From the ${ }^{1}$ Institute of Pathology, ${ }^{2}$ Dept of Neurosurgery, and ${ }^{3}$ Dept of Diagnostic Roentgenology, Odense \\ University Hospital, DK-5000 Odense C, Denmark
}

SUMMARY Material from 100 consecutive operations on herniated discs has been investigated for amyloid. Various degrees of amyloid degeneration were found in disc tissue from 41 patients. Material from patients over 50 years old showed significantly more amyloid than that from younger patients; there was no sex difference. Eighteen patients had previously been operated on for herniated discs; seven of these $(39 \%)$ had pyrophosphate deposits in their disc tissue, often in close topographical relation to amyloid. $26 \%$ of the patients had calcium phosphate deposits and $29 \%$ had slight inflammation-both without relation to amyloid. No pathogenetic correlation between amyloid degeneration and herniation of intervertebral disc tissue could be shown.

Amyloid deposits in intervertebral discs were first described by Bywaters and Dorling in $1970^{1}$ in a patient with myelomatosis and amyloid in several organs and joints. Amyloid in disc tissue has also been described in association with severe primary amyloidosis. $^{2}$ More recently, amyloid has been described in tissue from surgically removed herniated intervertebral discs. ${ }^{34}$ One of us (CL) has just shown a very high incidence of amyloid degeneration of the vertebral column in a consecutive series of non-selected autopsies.

The object of the present investigation has been to ascertain the occurrence of amyloid in tissue from 100 consecutive operations on herniated discs and to relate the findings to age, previous surgery on the vertebral column, and to other histopathological changes.

\section{Materials and methods}

Tissue from 100 consecutive operations on herniated discs performed at the neurosurgical department, Odense University Hospital were studied by light microscopy and electron microscopy.

Immediately after operation all the removed tissue was fixed in $10 \%$ formalin for at least 24

Accepted for publication 13 August 1985.

Correspondence to $\mathrm{Dr}$ Chr Ladefoged, Institute of Pathology, Odense University Hospital, DK-5000 Odense C, Denmark. hours. $6 \mu \mathrm{m}$ thick paraffin sections were then stained with haematoxylin and eosin, van Gieson's connective tissue stain, and with alkaline Congo red according to the method described by Puchtler et al. ${ }^{5}$

Amyloid was considered present when an orange colour in the alkaline Congo red stain showed green dichroism in polarised light.

Sections from 10 of the amyloid positive discs were used to check the sensitivity of the Congo red stain to pretreatment with $\mathrm{KMnO}_{4}$ according to the method described by Wright et al. ${ }^{6}$

Further, minimal tissue blocks $(1 \times 1 \times 1 \mathrm{~mm})$ were removed from the primarily formalin fixed material and postfixed in $2.5 \%$ glutaraldehyde in cacodylate buffer for electron microscopy. After 24 hours' fixation this tissue was rinsed in $10 \%$ sucrose in cacodylate buffer and postfixed in $1 \%$ osmium tetroxide for two hours. Thereafter it was dehydrated in alcohol and propylene oxide, embedded in Epon, and cut on an ultramicrotome (Reichart). The ultrastructural studies were carried out on a Philips EM 201 electron microscope.

\section{Results}

The average age of the 63 men operated on was $42 \cdot 9$ years (range 21-67) and for the 37 women $45 \cdot 7$ years (range 22-69). The age distribution is shown in Table 1. Eighteen had previously been operated on 
Table 1 Frequency of various histopathological changes in intervertebral disc tissue and previous operation correlated with age

\begin{tabular}{lccccc}
\hline Age (years) & No of patients & Amyloid & Pyrophosphate & Ca phosphate & Inflammation \\
\hline $21-30$ & 8 & $0(0 \%)$ & 1 & 1 & 1 \\
$31-40$ & 33 & $10(30 \%)$ & 1 & 9 & 12 \\
$41-50$ & 36 & $16(44 \%)$ & 4 & 12 & 8 \\
$51-60$ & 13 & $7(54 \%)$ & 1 & 2 & 4 \\
$61-70$ & 10 & $8(80 \%)$ & 1 & 2 & 4 \\
Total & 100 & 41 & 8 & 26 & 10 \\
\hline
\end{tabular}

for herniation of disc tissue, 10 at the same level, six at a level just above or below the actual, and two at the same and a level just below. None of the patients suffered from primary amyloidosis, rheumatoid arthritis, tuberculosis, or myelomatosis; one had diabetes mellitus. Amyloid deposits in disc tissue were found in 41 of the 100 operated patients (Table 1).

The amyloid degeneration was of varying degree and the amyloid was primarily localised to collagen rich material from the annulus fibrosus (Figs 1 and 2 ), but in 11 cases it was seen also in the looser fibrocartilage from the nucleus pulposus.

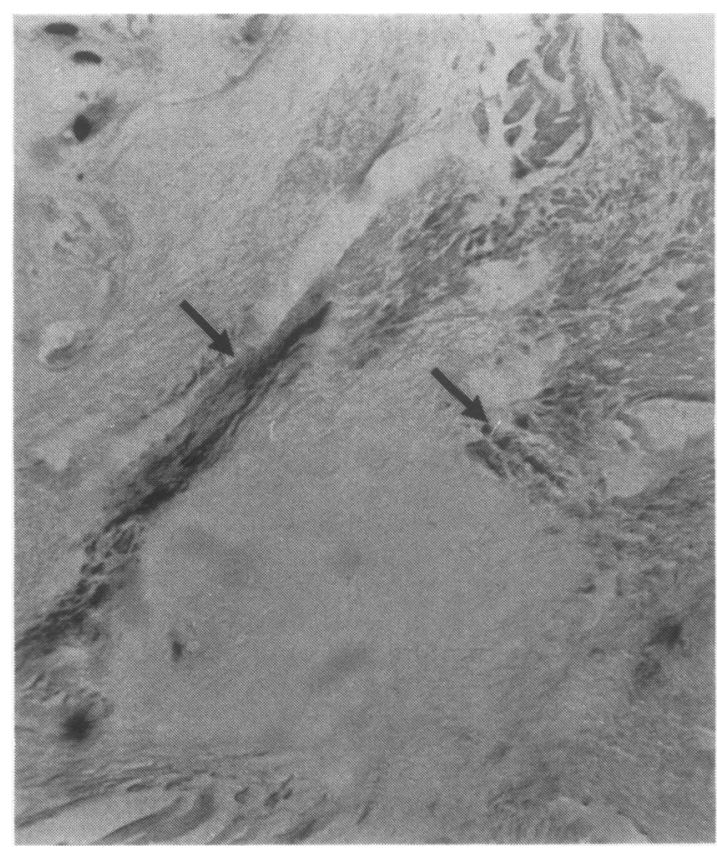

Fig. 1 Amyloid deposits (arrows) in fibrillary substance from the annulus fibrosus. (Alkaline Congo red, $\times 250)$.
Ultrastructurally, collagen fibres were partly re-ic placed by material consisting of irregularly arrangedi straight fibrils 8-25 nm thick (Fig. 3), characteristice्w of amyloid. ${ }^{?}$

After treatment with $\mathrm{KMnO}_{4}$ the amyloid re-을 tained its stainability with alkaline Congo red, $\rightarrow \vec{\rightarrow}$ including the green dichroism in polarised light.

Significantly more amyloid was found among patients over 50 years of age (Table 2). On the otherhand, no sex difference was found in relation to the $e_{\infty}^{\infty}$ extent of amyloid deposition.

Eighteen patients (11 male, 7 female) had previously been operated on for herniated discs. Ten of

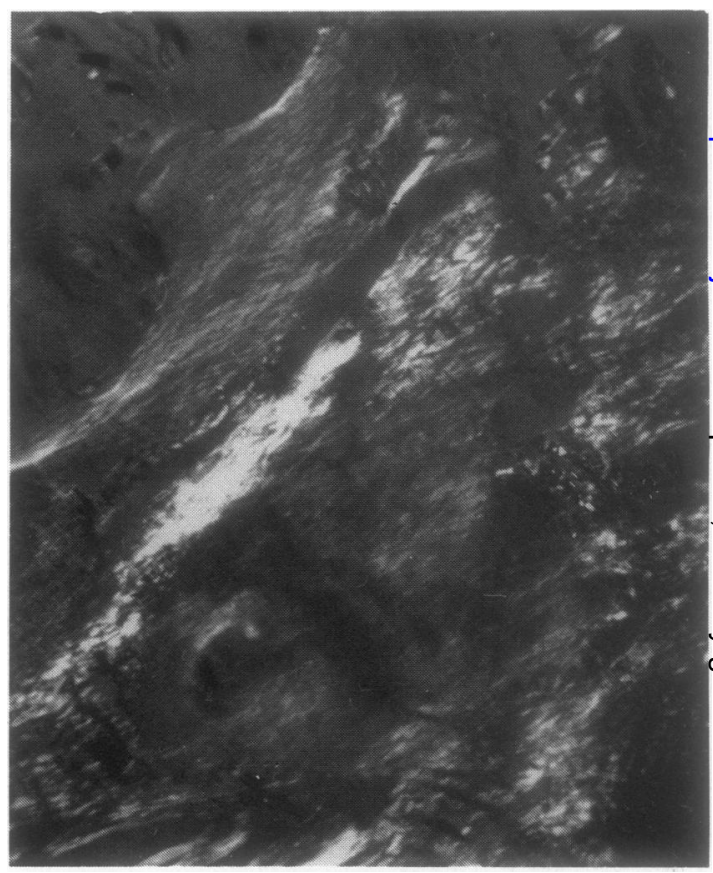

Fig. 2 Same as Fig. 1, by polarised light.

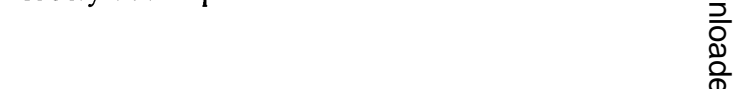




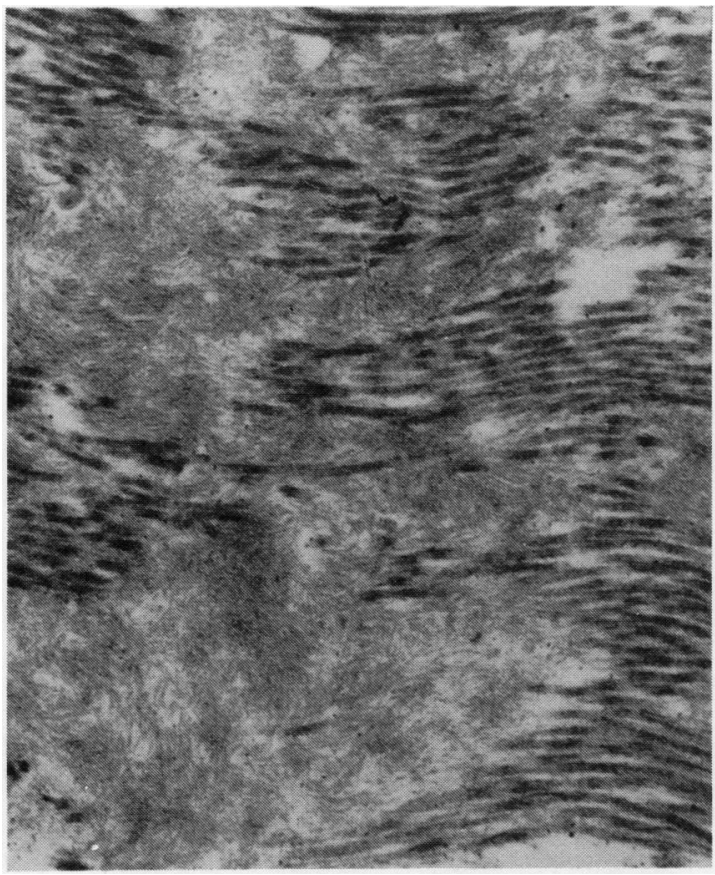

Fig. 3 Electron micrograph showing parallel cross striated collagen fibres between masses of thinner fibrils lying criss cross to each other. $(\times 19000)$.

these had amyloid deposits in their disc tissue $(56 \%)$. This is not significantly different from the material as a whole. In tissue from eight herniated discs (six from men and two from women) calcium pyrophosphate dihydrate (pyrophosphate) was found. The pyrophosphate appeared as rhomboid or rod shaped crystals measuring 5-15 $\mu \mathrm{m}$ in length, lying between the collagen fibres, and in six of the eight cases in close proximity to amyloid (Fig. 4). Seven of the eight patients with pyrophosphate

Table 2 Significantly more amyloid was found in the group of patients over 50 years of age $\left(\chi^{2}\right.$ test: $\left.p<0.01\right)$

\begin{tabular}{llll}
\hline Age (years) & Amyloid & \multicolumn{2}{c}{ Total } \\
\cline { 2 - 3 } & Negative & Positive & \\
\hline$<50$ & 51 & 26 & 77 \\
$>50$ & 8 & 15 & 23 \\
Total & 59 & 41 & 100 \\
\hline
\end{tabular}

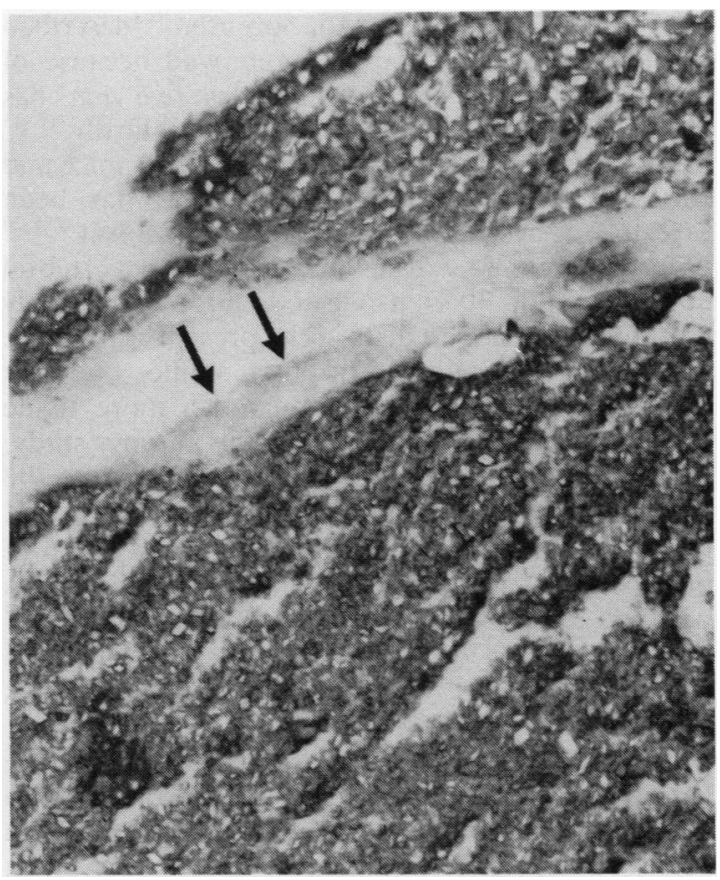

Fig. 4 Amyloid deposits (arrows) in close proximity to pyrophosphate, lying as rhomboid or rod shaped crystals in the disc tissue. (Alkaline Congo red, $\times 350$ ).

deposits had previously been operated on for herniated discs. In other words, among the 18 patients previously operated upon, seven $(39 \%)$ had developed pyrophosphate in their disc tissue.

In tissue from 26 patients (15 male, 11 female) focal deposits of calcium phosphate were found. These deposits had no topographical relationship to amyloid, nor was there any association with sex, age, or previous surgery.

Slight infiltration of lymphocytes was seen in 29 discs. No correlation between these changes and amyloid was shown. Patients previously operated on for herniated discs did not exhibit more inflammation than other patients. Slight inflammatory changes were seen around most of the pyrophosphate deposits, while calcium deposits did not provoke any inflammatory reaction.

\section{Discussion}

In the last 100 years several reports of articular amyloid have appeared, primarily as case reports describing severe amyloid arthropathy in association with myelomatosis, ${ }^{8-11}$ primary amyloidosis, ${ }^{112}$ and rheumatoid arthritis. ${ }^{13-15}$ 
In 1972 Christensen and Sørensen ${ }^{16}$ described amyloid in hip joint capsules removed because of osteoarthritis, but only during the last five years has joint amyloid been studied more systematically. ${ }^{17-23}$

Recently, intervertebral disc tissue from mice and from surgically removed human discs has been investigated systematically for amyloid deposit. ${ }^{34} 24$ One of us has found amyloid in $93 \%$ of vertebral columns from 30 non-selected autopsies. ${ }^{25}$ Only $41 \%$ of the herniated discs in the present study were positive for amyloid. The two studies are not comparable, however, because much more tissue was available for examination in the autopsy study. On the other hand, amyloid seems not to be concentrated preferentially in herniated disc tissue.

As in the autopsy material amyloid deposition in prolapsed disc tissue increases with age. This agrees with the findings of Takeda et al. ${ }^{4}$ Shimizu et al. ${ }^{24}$ found the same age relationship in their study of amyloid deposition in intervertebral discs of mice with accelerated senescence.

Both in the present investigation and in the autopsy study the disc amyloid was stained with alkaline Congo red and gave a green dichroism in polarised light after treatment with $\mathrm{KMnO}_{4}$, which means that it is of a non-amyloid $\mathrm{A}$ (non-secondary) type. ${ }^{6}$

In $8 \%$ of the investigated herniated discs pyrophosphate was found-in six cases in close proximity to amyloid. The same close relationship between pyrophosphate and amyloid was found in the autopsy material and in hip joint studies. ${ }^{20} 2326$ The incidence of pyrophosphate in the intervertebral disc tissue was higher in the autopsy material $(20 \%)$, but as mentioned above much more tissue was available in the autopsy study.

Seven of the 18 patients previously operated on for herniated discs had developed pyrophosphate in their disc tissue $(39 \%)$. This is a somewhat higher incidence than the $10 \%$ reported by Andres and Trainer $^{27}$ and supports their conclusion that pyrophosphate deposition (chondrocalcinosis) is more frequent in patients who have had prior surgical procedures in the same or adjacent disc spaces.

Calcification of disc tissue has previously been considered a rare finding. ${ }^{2 \overline{7}-2 \hat{9}} 26 \%$ of the discs investigated in this study contained deposits of calcium phosphate without topographical relationship to amyloid.

Because herniation of disc tissue occurs most frequently in people between 30 and 50 years of age (Table 1) $)^{30}$ and amyloid degeneration increases significantly with older age and is found in a high proportion among autopsies of patients without earlier back complaints, ${ }^{25}$ we conclude that there is probably no pathogenetic connection between amy- $\overrightarrow{\vec{F}}$ loid degeneration and herniation of intervertebral discs.

\section{References}

1 Bywaters E G L, Dorling J. Amyloid deposits in articular cartilage. Ann Rheum Dis 1970; 29: 294-306.

2 Ballou S P, Kahn M A. Kushner I. Diffuse intervertebral disc calcification in primary amyloidosis. Ann Intern Med 1976; 85: $\overrightarrow{0}$ 616-7.

3 Wagner T, Mohr W. Age distribution of amyloid in the intervertebral disc. Ann Rheum Dis 1984; 43: 663-4.

4 Takeda T, Sanada H, Ishii M, et al. Age-associated amyloid deposition in surgically removed herniated intervertebral discs. Arthritis Rheum 1984; 27: 1063-5.

5 Puchtler H, Sweat F, Levine M. On the binding of Congo red by amyloid. J Histochem Cytochem 1962; 10: 355-64.

6 Wright J R, Calkins E, Humphrey R L. Potassium permanganate reaction in amyloidosis. Lab Invest 1977; 36: 274-81.

7 Shirahama T, Cohen A S. High resolution electron microscopy 윽 analysis of the amyloid fibril. J Cell Biol 1967; 33: 679-708.

8 Kruse P. Amyloid artropati. Ugeskr Laeger 1971; 133: 1777-9.

9 Wiernik P H. Amyloid joint disease. Medicine (Baltimore) 1972; 51: 465-79.

10 Kavanaugh J H. Multiple myeloma, amyloid arthropathy and pathological fractures of the femur. $J$ Bone Joint Surg [Am] 1978; 60: 135-7.

11 French B T. Amyloid arthropathy in myelomatosisintracytoplasmatic synovial deposits. Histopathology 1980; 4: 21-8.

12 Gamarski J, Netto M B. Manifestaqoes osteo-articulares na amyloidose primaria-apresentaqao de caso. Arch Interamer Rheumatol 1959; 2: 651-3.

13 Laine V, Vainio K, Ritana V V. Occurrence of amyloid in rheumatoid arthritis. Acta Rheumatol Scand 1955; 1: 43-6.

14 Linke R P, König G. RA und Amyloidose. Diagnostische Signifikanz eines löslichen, synoviale Proteins mit immunologisher Kreüzreaktion mit dem Amyloid-fibrillen Protein A. Verh Dtsch Ges Rheumatol 1978; 5: 330-3.

15 Liard M E, Cywiner-Golenzer Ch, Leclerc J P. Les microdepots amyloides en rheumatologie. Arch Anat Cytol Pathol 1979; 27: 343-6.

16 Christensen H E, Sørensen K H. Local amyloid formation of capsula fibrosa in arthrosis coxae. Acta Pathol Microbiol Immunol Scand [Suppl] 1972; 233: 128-31.

17 Ladefoged C, Christensen H E. Congophilic substance with green dichroism in hip joints in autopsy material. Acta Pathol Microbiol Immunol Scand $[A]$ 1980; 88: 55-8.

18 Goffin Y A, Thoua Y, Potvliege P R. Microdeposition of $D$ amyloid in the joints. Ann Rheum Dis 1981; 40: 27-33.

19 Ladefoged C. Amyloid deposits in human hip joints. Acta Pathol Microbiol Immunol Scand [A] 1982; 96: 2-10. N

20 Ladefoged C. Amyloid in osteoarthritic hip joints. Acta Orthop Scand 1982; 53: 581-6.

21 Ladefoged C, Christensen H E, Sørensen K H. Amyloid in N osteoarthritic hip joints. Acta Orthop Scand 1982; 53: 587-90.

22 Egan M W, Goldenberg D F, Cohen A S, Segal D. The association of amyloid deposits and osteoarthritis. Arthritis 0 Rheum 1982; 25: 204-8.

23 Ladefoged C. Amyloid in osteoarthritic hip joints: deposits in relation to chondromatosis, pyrophosphate, and inflammatory cell infiltrate in the synovial membrane and fibrous capsule. Ann Rheum Dis 1983; 42: 659-64.

24 Shimizu K, Ishii M, Yamamuro T, Takeshita S, Hosokawa M, Takeda T. Amyloid deposition in intervertebral discs of senescence-accelerated mice. Arthritis Rheum 1982; 25: 710-2.

25 Ladefoged C. Amyloid in intervertebral discs. (A histopatholo- 
gical investigation of intervertebral discs from 30 randomly selected autopsies). Appl Pathol (in press).

26 Teglbjerg P S, Ladefoged C, Sørensen K H, Christensen H E. Local articular amyloid deposition in pyrophosphate arthritis. Acta Pathol Microbiol Immunol Scand [A] 1979; 87: 307-11.

27 Andres T L, Trainer T D. Intervertebral chondrocalcinosis. A coincidental finding possibly related to previous surgery. Arch Pathol Lab Med 1980; 104: 269-71.
28 Maccartee C C, Griffin P P, Byrd E B. Ruptured calcified thoracic disc in a child. J Bone Joint Surg [Am] 1972; 54: 1272-4.

29 Weinberger A, Myers A R. Intervertebral disc calcification in adults. A review. Semin Arthritis Rheum 1978; 8: 69-75.

30 Kelsey J L, Githens P B, Walter S D, et al. An epidemiological study of acute prolapsed cervical intervertebral disc. $J$ Bone Joint Surg [Am] 1984; 66: 907-14. 